\title{
RANCANG BANGUN SISTEM PENYIRAMAN TANAMAN ANGGREK DENDROBIUM MENGGUNAKAN SENSOR SHT11 PADA FASE PEMBUNGAAN
}

\author{
Chusniati Dhonny ${ }^{1)}$ dan Widodo ${ }^{1)}$ \\ ${ }^{1)}$ Program Studi Teknik Elektro, Fakultas Teknologi Industri \\ Universitas PGRI Adi Buana Surabaya \\ Email: chusniatidhonny@gmail.com
}

\begin{abstract}
Abstrak
Penelitian ini bertujuan merancang sistem penyiraman tanaman anggrek Dendrobium dengan memperhatikan kebutuhan suhu dan kelembaban udara terhadap waktu penyiraman serta pembuatan desain sistem yang dapat ditempatkan secara praktis. Penelitian ini menggunakan sensor SHT1 1 untuk mendeteksi suhu dan kelembaban udara didalam naungan(paranet) tanaman anggrek Dendrobium pada fase pembungaan. Metode penelitian yang digunakan dalam penelitian ini yaitu metode observasi dan percobaan dengan variabel suhu $28,30,32^{\circ} \mathrm{C}$ serta kelembaban udara 60,70,80RH\%. Adapun objek yang digunakan dalam penelitian ini yaitu anggrek Dendrobium fase pembungaan. Hasil dari penelitian ini menunjukkan bahwa dengan memberikan variabel berbeda-beda. Sistem penyiraman dapat bekerja dengan baik, dimana pompa air $($ On) bekerja pada saat kelembaban udara menurun untuk melakukan penyiraman dan kipas (On) berjalan pada saat suhu naik dari nilai yang ditentukan.
\end{abstract}

Kata kunci: Anggrek Dendrobium Fase Pembungaan, Arduino Uno R3, Sensor SHT11, Sistem Penyiraman

\begin{abstract}
This study aims to design systems watering orchidaceous plants Dendobium with incorporate the needs of temperatures and humidity air respect to time watering and the system design that can be placed in practice. This research means of sensor SHT11 to detect temperatures and humidity air in shade(paranet) orchidaceous plant Dendrobium in phase of flowering. Reasearch Methodology used in research is amethod of observation and experiments with variable temperature $32^{\circ} \mathrm{C}, 30^{\circ} \mathrm{C}, 28^{\circ} \mathrm{C}$ andair humidity $60 \%, 70 \%, 80 \%$. As for object used in research is orchids Dendrobium phase of flowering. The result of the research indicated that by giving variable different. Watering system can work well, where water pump $($ On $)$ work at the time moisture descending air to do watering and fan $(\mathrm{On})$ walking on when the temperatureup from a specified value.
\end{abstract}

Keywords: Arduino Uno R3, Cents SHT11, Orchid Dendrobium Phase Flowering, Watering System 

menggunakan Sensor SHT11 pada Fase Pembuangan

\section{PENDAHULUAN}

Dendrobium merupakan salah satu anggrek yang berpotensi untuk terus dikembangkan karena memiliki beragam jenis bentuk, warna dan ukurannya. Selain itu anggrek Dendrobium juga dapat dijadikan sebagai bunga potong maupun sebagai bunga pot. Produksi anggrek potong tahun 2007 menduduki urutan ke-5 setelah gladiol yaitu sebanyak 9.484.393 (Andalasari dkk., 2014). Usaha tanaman anggrek Dendrobium pada fase pembungaan memiliki prospek yang cukup baik dalam dunia bisnis tanaman hias, karena mempunyai nilai jual yang tinggi dan menjanjikan keuntungan besar dan permintaan tanaman anggrek selalu meningkat dari tahun ke tahun. Menurut Rukmana (1997) dalam Kurniati dkk. (2007), meningkatnya permintaan tanaman anggrek disebabkan oleh semakin meningkatnya jumlah penduduk, perluasan pemukiman, meningkatnya pendapatan dan kesadaran akan pentingnya lingkungan hidup yang nyaman. Untuk menghasilkan pembungaan anggrek Dendrobium, pembudidaya tanaman anggrek hanya memerlukan waktu perawatan tanaman selama 3-4 bulan dari mulai perawatan tanaman dewasa sampai tanaman berbunga dan kemungkinan kegagalan pada tahap ini jauh lebih kecil dibandingkan dengan bibit kompot yang membutuhan waktu yang relatif lebih lama (Santo, 2006). Kebutuhan tanaman agar cepat berbunga memerlukan perawatan yang tepat, salah satunya yaitu teknik penyiraman. Dengan melakukan penyiraman yang tepat waktu serta memperhatikan faktor suhu dan kelembaban udara dapat memenuhi kebutuhan tanaman anggrek khususnya Dendrobium, sehingga menghasilkan bunga yang banyak dan bertumbuh sehat. Suhu dan kelembaban udara akan terpenuhi apabila suhu didalam naungan (paranet) tanaman anggrek Dendrobium berkisar $2832^{\circ} \mathrm{C}$ pada fase pembungaan dan kelembaban udara berkisar antara $60-80 \%$.

Pendeteksian nilai suhu dan kelembaban udara pada proses penyiraman juga perna dilakukan oleh penelitian sebelumnya Arif (2015), yaitu dengan menggunakan 2 sensor. Sensor LM35 untuk mendeteksi suhu dan sensor 808H3V3 untuk mendeteksi kelembaban udara serta waktu penyiraman disesuaikan dengan pewaktu smart relay. Seluruh masukan tersebut deprogram dengan menggunakan ZELIO SOFT. Sistem dapat bekerja apabila suhu minimal $30^{\circ} \mathrm{C}$ dan kelembaban maksimal $70 \%$. Penelitian berikutnya tentang pengontrolan system penyiraman dengan menggunakan mikrokontroller Atmega328P yang dilakukan oleh Gani (2014), menunjukkan bahwa pengontrolan system penyiraman tanaman cabai dapat bekerja secara otomatis dan mampu mengontrol keadaan tanah pada kelembaban tanah $60 \%$. Sehingga tanaman cabai tumbuh dengan subur.

Berdasarkan penelitian-penelitian sebelumnya, maka peneliti disini mengembangkan penelitian dengan menggunakan sensor SHT11 untuk mendeteksi nilai suhu dan kelembaban udara didalam naungan (paranet) tanaman anggrek Dendrobium serta Arduino Uno R3 untuk mengendalikan sistem tersebut. Sensor SHT11 adalah suatu modul chip multi sensor suhu dan kelembaban relatif yang menghasilkan keluaran digital yang terkalibrasi. Modul ini dapat digunakan sebagai alat pengindra suhu dan kelembaban dalam aplikasi pengendali suhu dan kelembaban ruangan maupun aplikasi pemantau suhu dan kelembaban relatif ruangan. Sensor SHT11 menggunakan antarmuka serial 2-wire dan regulasi tegangan internal, sehingga memudahkan dan mempercepat integrasi sistem (Hastuti, 2013).

Adapun tujuan penelitian ini yaitu merancang sistem penyiraman tanaman anggrek Dendrobium dengan memperhatikan kebutuhan suhu dan kelembaban udara terhadap waktu penyiraman serta membuat desain sistem penyiraman yang dapat ditempatkan secara praktis sesuai kondisi lingkungan.

\section{METODE}

Penelitian ini merupakan penelitian pengembangan sistem penyiraman anggrek dendrobium fase pembungaan. Untuk mempermudah penelitian, sistem dilakukan secara bertahap yakni persiapan, perancangan sistem, pembuatan desain, pengumpulan data, pengujian hingga analisis hasil sistem. 


\section{Persiapan}

Persiapan perancangan sistem dimulai dengan melakukan studi literatur tentang suhu dan kelembaban udara tanaman anggrek dendrobium fase pembungaan serta peralatan dan bahan yang digunakan dalm penelitian Adapun alat dan bahan yang digunakan adalah: (1) Digital Thermo-Hygrometer, (2) Multimeter, (3) Perangkat lunak IDE Arduino 1.6.7 dan ISIS Proteus Profesional, (4) Sensor SHT11, (5) Arduino Uno R3, (6) LCD, (7) Adaptor, (8) Aktuator (Pompa air dan Kipas DC 12V). Dalam persiapan juga ditentukan variabel yang digunakna dalam penelitian antara lain lain: (1) Variabel bebas yang terdiri dari Suhu $32^{\circ} \mathrm{C}, 30^{\circ} \mathrm{C}, 28^{\circ} \mathrm{C}$ dan kelembaban udara $60 \%, 70 \%, 80 \%$, (2) Variabel terikat atau variabel dependen adalah variabel yang dapat menjadi perhatian utama dalam sebuah pengamatan. Variabel terikat yang diteliti adalah kerja aktuator (Pompa air dan Kipas) saat On/Off selain itu desain sistem penyiraman yang ditempatkan sesuai dengan kondisi lingkungan. Serta Beberapa variabel kontrol dalam penelitian adalah (1) Alat ukur yang digunakan dalam pengujian sensor SHT11 untuk mengetahui kepekaan (sensitivitas) suhu dan kelembaban udara adalah Digital Thermo-hygrometer, (2) Alat ukur yang digunakan dalam pengujian pada tiap rangkaian sistem penyiraman yaitu multimeter.

\section{Perancangan sistem}

Penulis membuat perancangan sistem yang dibagi menjadi 3 bagian antara lain blok diagram system, perancangan perangkat keras dan perancangan perangkat lunak. Blok diagram Sistem ini dapat bekerja apabila Sensor SHT11 mendeteksi nilai suhu dan kelembaban udara yang sudah ditentukan. Dari nilai suhu dan kelembaban udara tersebut, selanjutnya diproses oleh Arduino Uno R3 untuk mengirimkan pada aktuator(pompa air dan kipas) dan menampilkanya pada LCD. Apabila suhu udara naik dan kelembaban udara menurun dari nilai yang ditentukan, maka Arduino Uno R3 akan memberikan perintah pada aktuator untuk menghidupkan (pompa air dan kipas). Sebaliknya apabila suhu udara turun dan kelembaban udara naik, maka Arduino Uno R3 akan memberikan isyarat untuk mematikan aktuator. Berikut ini gambar blok diagram sistem penyiraman.

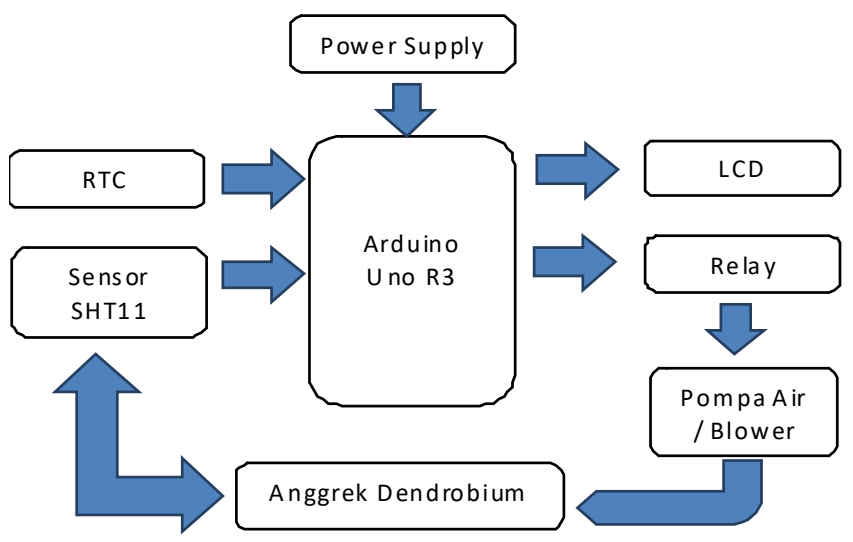

Gambar 1. Blok Diagram Sistem Penyiraman

Pada perancangan perangkat keras yang terdiri dari rangkaian Sensor SHT11, Arduino Uno, LCD, actuator (pompa air dan kipas) dan perancangan secara keseluruhan. Rangkaian Sensor SHT11 adalah suatu modul chip multi sensor suhu dan kelembaban relatif yang menghasilkan keluaran digital yang terkalibrasi. SHT11 memberikan keluaran data kelembaban dan temperatur pada pin Data secara bergantian sesuai dengan clock yang diberikan oleh Arduino pada pin 8. Sensor SHT11 memiliki ADC (Analog to Digital Converter) didalamnya sehingga keluaran data SHT11 sudahter konversi dalam bentuk digital dan tidak memerlukan ADC eksternal dalam pengolahan data pada Arduino(Aris,). Pada Sensor SHT11 sendiri terdiri dari 8 Pin. Namun yang digunakan untuk berkomunikasi dengan Arduino ada 4 Pin (Tabel 1). 
Tabel 1. Konfigurasi Sensor SHT-11 dengan Arduino Uno

\begin{tabular}{lll}
\hline \multicolumn{1}{c}{ Pin } & \multicolumn{1}{c}{ Name } & \multicolumn{1}{c}{ Coment } \\
\hline GND & GND & GROUND \\
8 & DATA & Serial data bedirectional \\
9 & SCK & Serial clock input \\
VCC & VCC & Suplay \\
\hline
\end{tabular}

Rangkaian arduino Uno R3 adalah board mikrokontroler berbasis ATmega328 yang memiliki 14 pin $\mathrm{I} / \mathrm{O}$ digital $(6$ pin diantaranya dapat digunakan sebagai output PWM), 6 analog dan clock yang digunakan $16 \mathrm{MHz}$ (xtal), port usb, jack power supply, dan tombol reset. Dalam sistem ini arduino uno berfungsi sebagai pusat pengendali sistem penyiraman dengan cara mengolah inputan suhudan kelambaban udara untuk menggerakkan aktuator berupa perintah On/Off ke pompa air dan kipas. Sedangkan rangkaian LCD digunakan sebagai menampilkan suhu, kelembaban dan mode sistem yang sedang berjalan. LCD yang digunakan berjenis LM016L atau LCD 16x2. Disini hubungan pin-pin dari LCD ke Arduino Uno R3 adalah (1) Pin 5V terhubung ke pin 5V dari Arduino Uno R3, (2) GND terhubung ke ground sistem Arduino Uno R3,
(3) Pin RS (register select) terhubung ke pin 2 pada Arduino Uno R3,(4)Pin E (enable) terhubung ke pin 3 pada Arduino Uno R3,(5)Pin D4,D5,D6,D7 terhubung ke pin 4, 5, 6, 7 pada Arduino Uno R3. Aktuator yang digunakan pada sistem ini yaitu kipas DC $12 \mathrm{~V}$ dan pompa air DC $12 \mathrm{~V} 2 \mathrm{~A}$. Untuk menghubungan aktuator dengan arduino, penulis menghubungkan kipas pada pin 10 dan pompa air pada pin 11. Perancangan Sistem Keseluruhan terdiri dari sensor SHT11, LCD, RTC DS3232, pompa air dan kipas dihubungkan ke Arduino Uno R3 menggunakan software ISIS Proteus 7 Profesional. Untuk mensimulasikan perangkat keras tersebut software ISIS Proteus 7 Profesional diisi listing program dari perangkat lunak Arduino IDE 1.6.7. Gambar 3 merupakan gambar perancangan sistem secara keseluruhan.

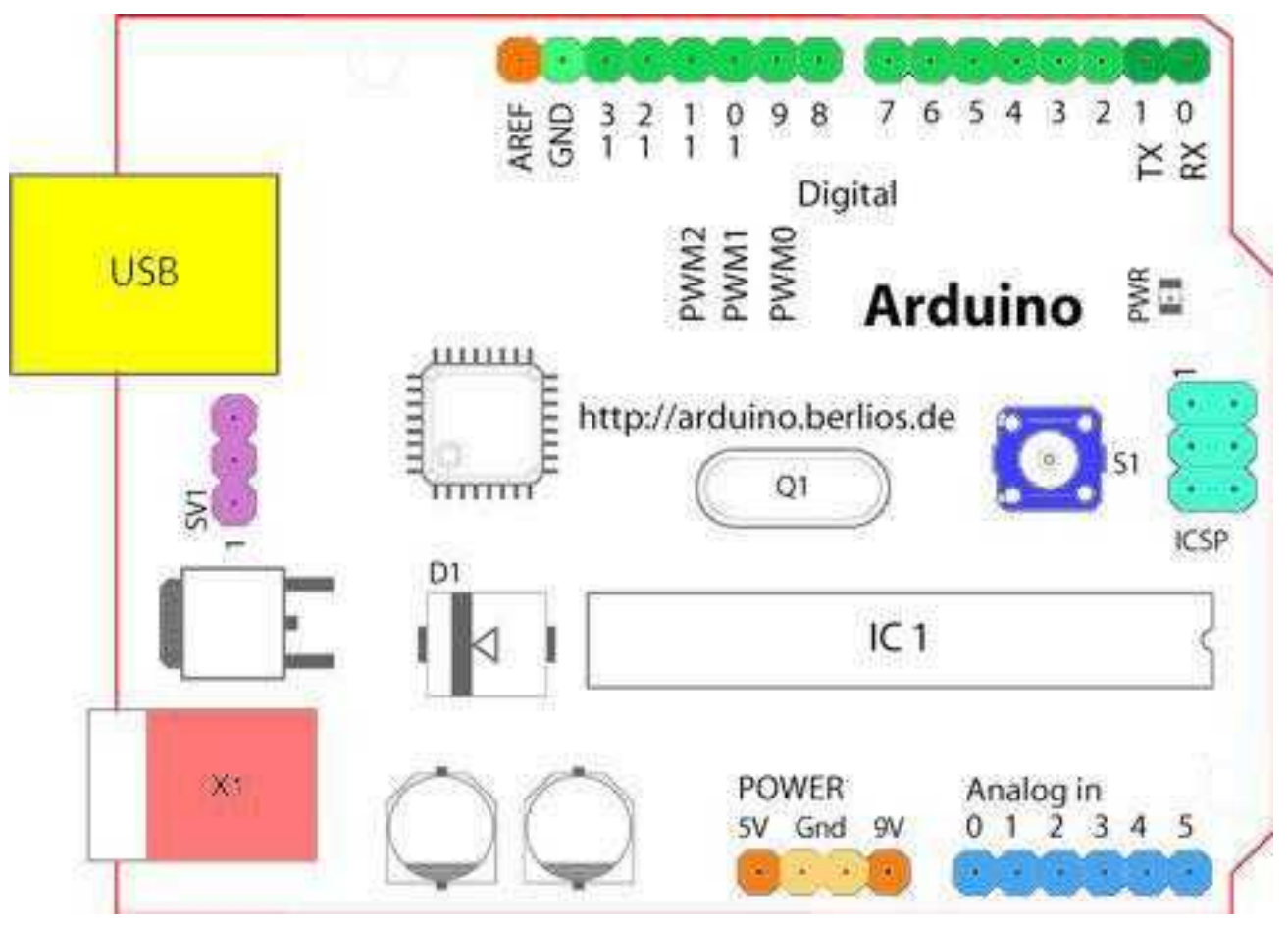

Gambar 2. Arduino Uno R3 (Sumber: Feri, 2011) 


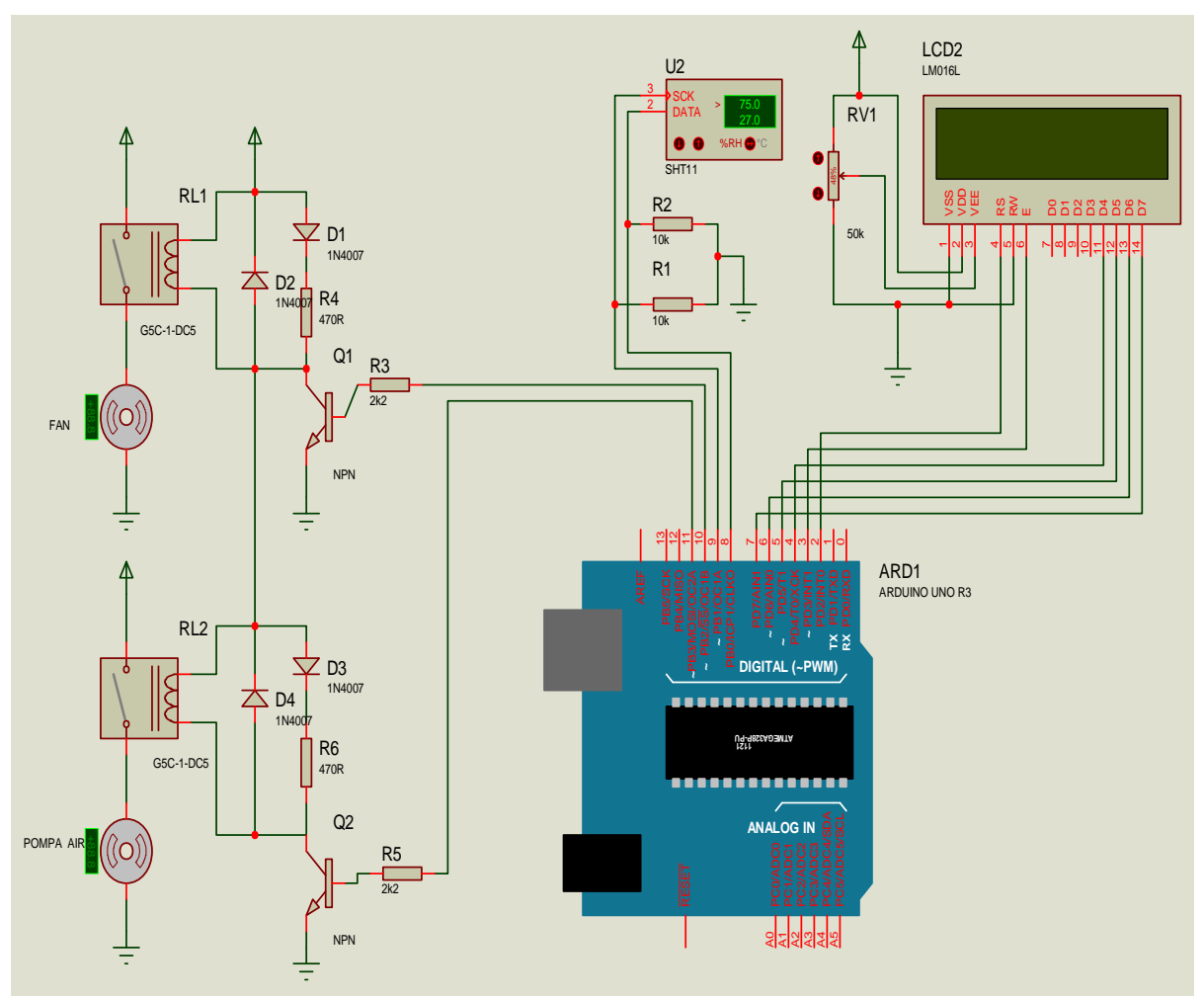

Gambar 3. Perancangan Sistem Secara Keseluruhan

\section{Pembuatan desain}

Pembuatan desain bertujuan sebagai naungan atau tempat pembudidayaan tanaman anggrek Dendrobium fase pembungaan yang dapat melakukan penyiraman secara otomatis dan dapat ditempatkan secara praktis di lingkungan sekitar. Desain ini berukuran 80x50x35 yang terbuat dari kayu dan paranet. Nilai suhu dan kelembaban udara di tempat ini yang digunakan sebagai penelitian dengan membandingkan nilai suhu dan kelembaban udara pada sensor SHT11 dan thermo- hygrometer serta dapat menjalankan sistem penyiraman secara keseluruhan. Sensor SHT11 berfungsi sebagai inputan sistem penyiraman, Perangkat sistem penyiraman berfungsi sebagai pengontrol dan penampil sistem penyiraman, Aktuator (pompa air dan kipas) berfungsi sebagai outputan sistem yang dibuat, Penampung air berfungsi sebagai persediaan air yang akan digunakan dalam proses penyiraman. Gambar desain sistem penyiraman disajikan pada Gambar 4.

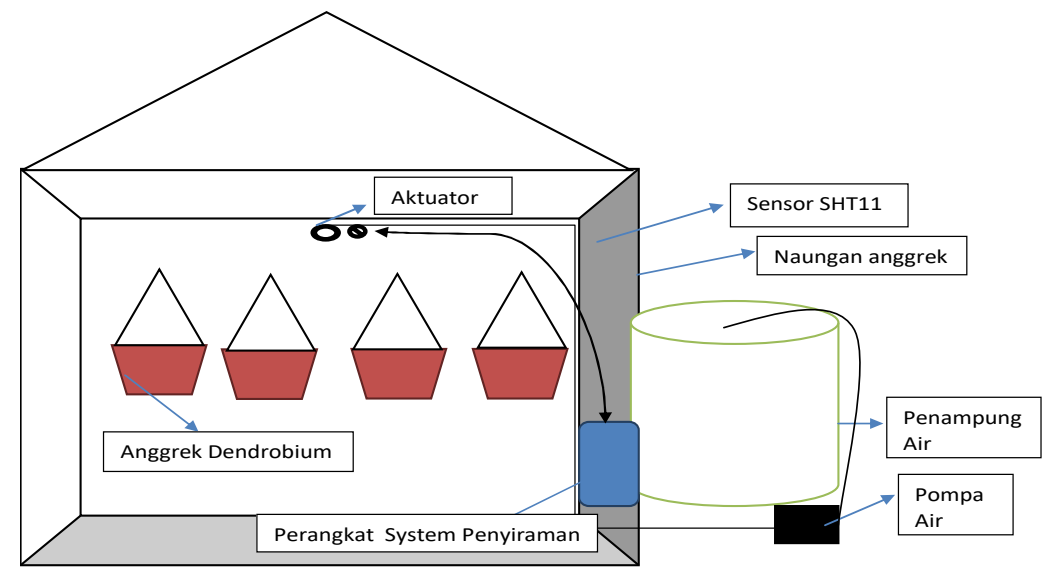

Gambar 4. Desain sistem penyiraman 


\section{Pengumpulan data}

Dalam penelitian ini metode pengumpulan data yang di gunakan adalah Observasi Terstruktur dan percobaan. Observasi Terstruktur yaitu observasi yang telah di rancang secara sistematis, tentang apa yang akan di amati, kapan dan di mana tempatnya. Jadi observasi terstruktur dilakukan apabila peneliti telah tahu dengan pasti tentang variabel apa yang akan di amati. Metode observasi ini di gunakan untuk mengamati proses awal hingga akhir sistem penyiraman (Ayik, 2015). Dalam metode percobaan ini dibahas pengujian sistem penyiraman guna mendapatkan hasil yang akan dianalisa, adapun pengujian sistem ini sebagai berikut: (1) Pengujian sensor SHT11, (2) Pengujian Arduino Uno R3,(3)Pengujian LCD,(4)Pengujian tegangan aktuator saat On/Off,(5)Pengujian sistem secara keseluruhan. Metode Analisis data yang digunakan adalah analisis percobaan untuk menganalisis kinerja dan keberhasilan sistem penyiraman. Disamping itu analisis diskriptif yaitu mendiskripsikan hasil percobaan melalui pengamatan dari pengujian sistem secara keseluruhan dengan variabel yang berbeda-beda. Diantaranya variabel yang digunakan yaitu: (1) Suhu $32^{\circ} \mathrm{C}$ dan Kelembaban $60 \% \mathrm{RH}$, (2) Suhu $30^{\circ} \mathrm{C}$ dan Kelembaban $70 \% \mathrm{RH}$, (3) Suhu $28^{\circ} \mathrm{C}$ dan Kelembaban $80 \%$ RH.

\section{HASIL DAN PEMBAHASAN}

Pada bagian ini dilakukan pengumpulan data-data hasil pengujian pada saat sistem penyiraman dijalankan. Data tersebut disajikan dalam bentuk tabel atau gambar/grafik. Diantaranya hasil pengujian tersebut yaitu:

\section{Pengujian sensor SHT11}

Pengujian ini menggunakan tanaman anggrek Dendrobium fase Pembungaan sebagai objek penelitian. Tujuan dari pengujian ini untuk mengetahui kepekaan (sensitivitas) suhu dan kelembaban udara didalam naungan anggrek Dendrobium.

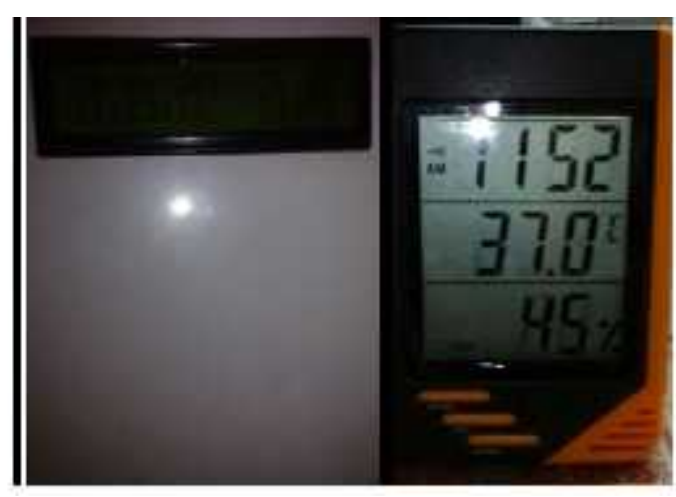

Gambar 5. Pengujian Sensor SHT11 dengan Digital Thermo-Hygrometer

Dari Gambar 5 dapat diketahui bahwa nilai suhu Sensor SHT11 36,20 ${ }^{\circ} \mathrm{C}$ dan kelembaban udaranya 51,6\%. Sedangkan nilai kelembaban Digital Thermohygrometer menunjukkan nilai $45 \%$ dengan niali suhu $37,0^{\circ} \mathrm{C}$. Dari kedua alat tersebut bawah nilai yang diuji tidak linier atau teratur. Hal tersebut terjadi dikarenakan sensitivitas serta keakuratan pada tiap sensor berbeda-beda. Aliran udara yang tidak stabil disekitar tanaman dapat mempengaruhi suhu dan kelembaban udara. Semakin tinggi nilai suhu, maka semakin rendah nilai kelembaban udara yang ada pada naungan anggrek dendrobium. Penelitian yang dilakukan (Ronaldo,2013) menunjukkan bahwa sensor SHT11 dan LM35DZ telah mampu merespon perubahan suhu dan kelembaban dengan baik. Dari hasil pengukuran diperoleh nilai suhu berbanding terbalik dengan nilai kelembaban.

\section{Pengujian Board Arduino Uno R3}

Pengujian ini berfungsi untuk mengetahui apakah pin-pin pada board arduino bekerja dengan baik atau tidak. Pengujian dilakukan dengan mengaktifkan rangkaian led pada pin -pin board arduino, kemudian board arduino diisi dengan program pada software IDE (Integrated Development Environment) arduino 1.6.7. Berdasarkan Gambar 6 hasil pengujian board arduino, telah menunjukkan bahwa pin-pin pada board arduino telah bekerja. Rangkaian led menyala secara bersama-sama selama 1 menit. 


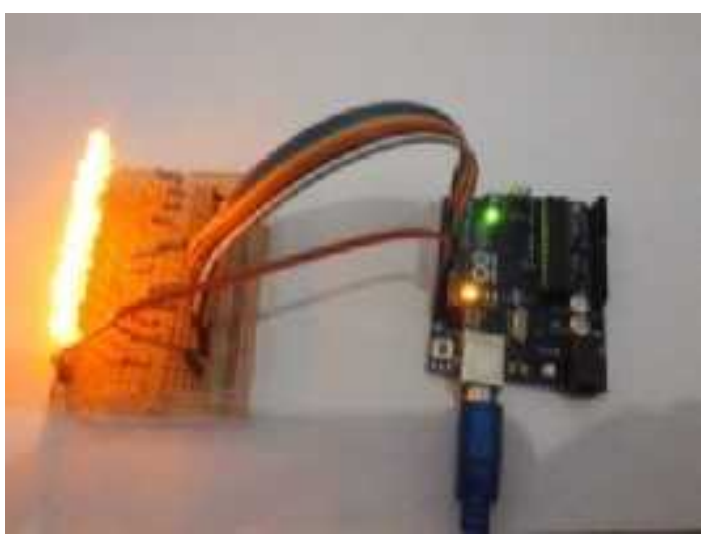

Gambar 6. Pengujian Board Arduino dengan Rangkaian led

\section{Pengujian LCD}

Pengujian LCD bertujuan untuk mengetahui apakah LCD bisa menampilkan sistem atau tidak. Cara pengujiannya dengan memberikan program yang sudah ada pada software IDE arduino 1.6.7. Dari Gambar 7 dapat diketahui bahwa pengujian LCDberhasil menampilkan system penyiraman menggunakan software IDE Arduino 1.6.7.

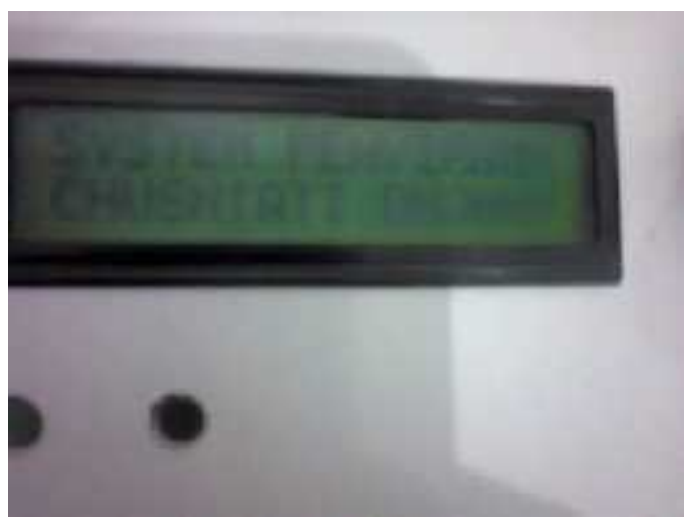

Gambar 7. Pengujian LCD menggunakan IDE Arduino 1.6.7.

\section{Pengujian Aktuator (pompa air dan kipas) saat On-Off}

Pengujian aktuator (pompa air dan kipas) saat On-Off bertujuan untuk mengetahui nilai tegangan saat actuator bekerja On dan Off. Pengujian ini menggunakan multimeter untuk mengukur tegangan actuator. Dari data-data hasil pengujian tegangan aktuator saat On-Off dapat diketahui bahwa aktuator kipas On saat nilai tegangan $12,04 \mathrm{~V}$ dan pompa On dengan tegangan $11,84 \mathrm{~V}$.

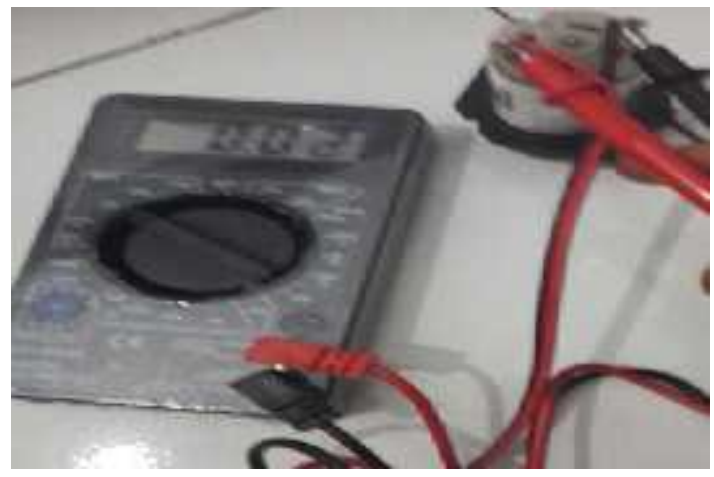

Gambar 8. Pengujian pompa air saat Off

Tabel 2. Data Hasil Pengujian tegangan aktuator saat On-Off

\begin{tabular}{llrc}
\hline No & Aktuator & \multicolumn{2}{c}{ Tegangan Output } \\
On & Off \\
\hline 1 & Kipas & 12,04 & 0,01 \\
2 & Pompa & 11,84 & 0,02 \\
\hline
\end{tabular}

\section{Pengujian Sistem Secara Keseluruhan}

Pengujian pada bagian ini sangat penting karena menjadi tolak ukur keberhasilan dari penelitian ini. Pengujian dilakukan dengan cara mengamati secara langsung dan dilaksanakan saat cuaca panas. Agar menghasilkan sistem penyiraman yang dapat bekerja dengan baik, maka diberikan variabel suhu dan kelembaban yang berbeda-beda sesuai dengan kebutuhan tanaman anggrek dendrobium fase pembugaan. Diantara variabel yang digunakan adalah:

a. Suhu $32^{\circ} \mathrm{C}$ dan Kelembaban $60 \% \mathrm{RH}$,

b. Suhu $30^{\circ} \mathrm{C}$ dan Kelembaban $70 \% \mathrm{RH}$,

c. Suhu $28^{\circ} \mathrm{C}$ dan Kelembaban $80 \% \mathrm{RH}$

Tabel 3. Hasil Pengamatan I Pada Suhu $32^{\circ} \mathrm{C}$ dan Kelembaban $60 \%$ RH

\begin{tabular}{llllllll}
\hline $\begin{array}{l}\text { Menit } \\
\text { Ke }\end{array}$ & Jam & $\begin{array}{l}\text { Suhu } \\
{ }^{\circ} \mathrm{C}\end{array}$ & $\begin{array}{l}\text { Kelembaban } \\
\% \text { RH }\end{array}$ & Kipas & $\begin{array}{l}\text { Indikator } \\
\text { LED } \\
\text { Kuning }\end{array}$ & Pompa & $\begin{array}{l}\text { Indikator } \\
\text { LED } \\
\text { Hijau }\end{array}$ \\
\hline 1 & $13: 02$ & 31,53 & 66,21 & OFF & Mati & OFF & Mati \\
2 & $13: 03$ & 31,65 & 66,47 & OFF & Mati & OFF & Mati \\
3 & $13: 04$ & 31,74 & 65,87 & OFF & Mati & OFF & Mati \\
4 & $13: 05$ & 31,84 & 65,7 & OFF & Mati & OFF & Mati \\
5 & $13: 06$ & 31,95 & 65,66 & OFF & Mati & OFF & Mati
\end{tabular}



menggunakan Sensor SHT11 pada Fase Pembuangan

\begin{tabular}{lcllllll}
\hline $\begin{array}{l}\text { Menit } \\
\text { Ke }\end{array}$ & Jam & $\begin{array}{l}\text { Suhu } \\
{ }^{\circ} \mathrm{C}\end{array}$ & $\begin{array}{l}\text { Kelembaban } \\
\% \text { RH }\end{array}$ & Kipas & $\begin{array}{l}\text { Indikator } \\
\text { LED } \\
\text { Kuning }\end{array}$ & Pompa & $\begin{array}{l}\text { Indikator } \\
\text { LED } \\
\text { Hijau }\end{array}$ \\
\hline 6 & $13: 07$ & 32,2 & 67,46 & ON & Hidup & OFF & Mati \\
7 & $13: 08$ & 32,37 & 66,65 & ON & Hidup & OFF & Mati \\
8 & $13: 09$ & 32,46 & 64,66 & ON & Hidup & OFF & Mati \\
9 & $13: 10$ & 32,56 & 64,08 & ON & Hidup & OFF & Mati \\
10 & $13: 11$ & 33,62 & 62,69 & ON & Hidup & OFF & Mati \\
11 & $13: 12$ & 34,31 & 59,13 & ON & Hidup & ON & Hidup \\
12 & $13: 13$ & 34,91 & 56,63 & ON & Hidup & ON & Hidup \\
13 & $13: 14$ & 34,98 & 57,93 & ON & Hidup & ON & Hidup \\
14 & $13: 15$ & 34,57 & 59,33 & ON & Hidup & ON & Hidup \\
15 & $13: 16$ & 34,63 & 58,16 & ON & Hidup & ON & Hidup \\
\hline
\end{tabular}

Pengamatan I dengan suhu $32^{\circ} \mathrm{C}$ dan kelembaban 60\% RH. Pada pengamatan I setiap nilai suhu diatas $32^{\circ} \mathrm{C}$ dan kelembaban dibawah 60\% RH maka kipas $(O n)$ dan pompa $(O n)$. Pada tabel 2.4 saat menit ke-11 nilai suhu mencapai $34,31^{\circ} \mathrm{C}$ kipas $(O n)$ dan kelembaban
59,13\%RH pompa $(O n)$. Namun apabila nilai suhu kurang dari $32^{\circ} \mathrm{C}$ dan kelembaban lebih dari $60 \%$ RH maka kipas (Off) dan pompa (Off). Pada menit ke-5 kipas dan pompa $(O f f)$, dikarenakan nilai suhu $31,84^{\circ} \mathrm{C}$ serta kelembaban $65,7 \% \mathrm{RH}$.

Tabel 4 Hasil Pengamatan II Pada Suhu $28^{\circ} \mathrm{C}$ dan Kelembaban $80 \%$ RH

\begin{tabular}{llllllll}
\hline $\begin{array}{l}\text { Menit } \\
\text { Ke }\end{array}$ & Jam & $\begin{array}{l}\text { Suhu } \\
{ }^{\circ} \mathrm{C}\end{array}$ & $\begin{array}{l}\text { Kelembaban } \\
\% \text { RH }\end{array}$ & Kipas & $\begin{array}{l}\text { Indikator } \\
\text { LED } \\
\text { Kuning }\end{array}$ & Pompa & $\begin{array}{l}\text { Indikator } \\
\text { LED } \\
\text { Hijau }\end{array}$ \\
\hline 1 & $16: 54$ & 0 & 0 & OFF & Mati & OFF & Mati \\
2 & $16: 55$ & 29.17 & 76.77 & ON & Hidup & ON & Hidup \\
3 & $16: 56$ & 29.14 & 76.65 & ON & Hidup & ON & Hidup \\
4 & $16: 57$ & 29.19 & 76.87 & ON & Hidup & ON & Hidup \\
5 & $16: 58$ & 29.2 & 77.22 & ON & Hidup & ON & Hidup \\
6 & $16: 59$ & 29.2 & 77.37 & ON & Hidup & ON & Hidup \\
7 & $17: 00$ & 29.14 & 77.88 & ON & Hidup & ON & Hidup \\
8 & $17: 01$ & 29.05 & 77.98 & ON & Hidup & ON & Hidup \\
9 & $17: 02$ & 29.09 & 78.11 & ON & Hidup & ON & Hidup \\
10 & $17: 03$ & 29.03 & 78.13 & ON & Hidup & ON & Hidup \\
11 & $17: 04$ & 29.02 & 78.3 & ON & Hidup & ON & Hidup \\
12 & $17: 05$ & 29.02 & 78.45 & ON & Hidup & ON & Hidup \\
13 & $17: 06$ & 28.97 & 78.03 & ON & Hidup & ON & Hidup \\
14 & $17: 07$ & 28.96 & 78.2 & ON & Hidup & ON & Hidup \\
15 & $17: 08$ & 28.97 & 78.09 & ON & Hidup & ON & Hidup \\
\hline
\end{tabular}

Pada pengamatan II suhu dan kelembaban yang digunakan yaitu suhu $28^{\circ} \mathrm{C}$ dan kelembaban $80 \% \mathrm{RH}$. Berdasarkan tabel 4 hasil pengamatan II, nilai suhu mengalami penurunan. Perununan suhu terjadi dikarenakan kipas menyala selama nilai suhu kurang dari $28^{\circ} \mathrm{C}$. Pada jam 17:01 suhu mengalami penurunan, dimana nilai suhu $29,14^{\circ} \mathrm{C}$ menjadi $29,05^{\circ} \mathrm{C}$. Sedangkan nilai kelembaban udara terus meningkat tiap menitnya. Pada jam 17:01 kelembaban udara naik $77,98 \%$ RH dari nilai kelembaban $77,88 \%$ RH. Hal ini terjadi karena pompa menyala secara terus menerus sampai nilai kelembaban lebih dari $80 \%$ RH. Namun actuator kipas dan pompa air tetap berjalan karena nilai suhu diatas $28{ }^{\circ} \mathrm{C}$ dan kelembaban udara kurang dari $80 \%$ RH. Pada penelitian Widhi dan Winarno (2017) menjelaskan bahwa sistem penyiraman otomatis telah bekerja dengan baik. Ketika suhu diatas $28 \mathrm{C}$ maka kipas 1 dan kipas 2 nyala untuk menurunkan suhu. Ketika 

menggunakan Sensor SHT11 pada Fase Pembuangan

kelembaban di bawah 60\% RH maka alarm penyiraman dengan menggunakan pompa berbunyi dan kemudian dilakukan sampai kelembaban mencapai $60 \% \mathrm{RH}$.

Tabel 5. Hasil Pengamatan Pada Suhu $30^{\circ} \mathrm{C}$ dan Kelembaban $70 \% \mathrm{RH}$

\begin{tabular}{llllllll}
\hline $\begin{array}{l}\text { Menit } \\
\text { Ke }\end{array}$ & Jam & $\begin{array}{l}\text { Suhu } \\
{ }^{\circ} \mathrm{C}\end{array}$ & $\begin{array}{l}\text { Kelembaban } \\
\% \text { RH }\end{array}$ & Kipas & $\begin{array}{l}\text { Indikator } \\
\text { LED } \\
\text { Kuning }\end{array}$ & Pompa & $\begin{array}{l}\text { Indikator } \\
\text { LED } \\
\text { Hijau }\end{array}$ \\
\hline 1 & $14: 44$ & 0 & 0 & OFF & Mati & OFF & Mati \\
2 & $14: 45$ & 0 & 0 & OFF & Mati & OFF & Mati \\
3 & $14: 46$ & 31,19 & 75,15 & ON & Hidup & OFF & Mati \\
4 & $14: 47$ & 30,82 & 74,87 & ON & Hidup & OFF & Mati \\
5 & $14: 48$ & 30,62 & 76,53 & ON & Hidup & OFF & Mati \\
6 & $14: 49$ & 30,61 & 75,76 & ON & Hidup & OFF & Mati \\
7 & $14: 50$ & 30,59 & 75,9 & ON & Hidup & OFF & Mati \\
8 & $14: 51$ & 30,48 & 75,43 & ON & Hidup & OFF & Mati \\
9 & $14: 52$ & 30,38 & 76,24 & ON & Hidup & OFF & Mati \\
10 & $14: 53$ & 30,47 & 75,76 & ON & Hidup & OFF & Mati \\
11 & $14: 54$ & 30,6 & 75,69 & ON & Hidup & OFF & Mati \\
12 & $14: 55$ & 30,58 & 75,09 & ON & Hidup & OFF & Mati \\
13 & $14: 56$ & 30,63 & 76,56 & ON & Hidup & OFF & Mati \\
14 & $14: 57$ & 30,39 & 74,76 & ON & Hidup & OFF & Mati \\
15 & $14: 58$ & 30,57 & 75,63 & ON & Hidup & OFF & Mati \\
\hline
\end{tabular}

Sedangkan pengamatan III dilakukan dengan set point suhu $30^{\circ} \mathrm{C}$ dan kelembaban $70 \%$ RH. Hasil pengamatan III menunjukkan bahwa nilai inputan dari suhu dan kelembaban udara dapat menjalankan kipas dan pompa sesuai dengan instruksi yang diberikan. Pada setting point suhu lebih dari $30^{\circ} \mathrm{C}$ pada sensor SHT11, arduino uno memerintakan kipas untuk hidup dan indikator led kuning menyala. Terlihat Tabel 2.6 pada menit ke-3 suhu tertinggi $31,19^{\circ} \mathrm{C}$ dan kipas $(O n)$. Pada menit yang sama kelembaban udara $75,15 \% \mathrm{RH}$ secara otomatis pompa tidak melakukan penyiraman karena nilai kelembaban lebih dari 70\%RH.

\section{KESIMPULAN}

Dari hasil pembahasan dapat diperoleh beberapa kesimpulan antara lain: (1) Rancangan sistem penyiraman tanaman anggrek Dendrobium dengan memperhatikan suhu dan kelembaban udara terhadap waktu penyiraman dapat bekerja dengan baik serta sesuai dengan kebutuhan fase pembungaan anggrek Dendrobium. (2) Desain sistem penyiraman yang dibuat dapat ditempatkan secara praktis dengan kondisi lingkungan tanaman anggrek Dendrobium. Adapun saran yang dapat diberikan pada penelitian ini adalah (1)Penggunaan naungan (paranet) harus disesuaikan dengan jenis intensitas cahaya anggrek yang digunakan dalam penelitian sehingga suhu dan kelembaban bisa stabil, (2)Diperlukan adanya alat ukur suhu dan kelembaban yang standart agar pengukuran suhu dan kelembaban lebih akurat, (3)Sebaiknya menggunakan keypad, remote maupun via sms untuk mempermudah setting point suhu dan kelembaban yang diinginkan, (4) Pengambilan data sebaiknya disesuaikan pada saat waktu penyiraman.

\section{UCAPAN TERIMA KASIH}

Terima kasih kepada Bapak Budi Prijo Sembodo, Bapak Muqtadiru serta Staff laboratorium teknik elektro Universitas Adi Buana Surabaya yang telah membantu dalam penelitian. 


\section{DAFTAR PUSTAKA}

Aris A., dkk, 2013. Rancang Bangun Penyiram tanaman Anggrek Menggunakan Sensor Kelembaban dengan Energi Alternatif Sinar Matahari. Tugas Akhir Elektro Industri, Politeknik Elektronika Negeri Surabaya

Andalasari, Tri Dewi, Yafisham dan Nuraini. 2014, Respon Pertumbuhan Anggrek Dendrobium Terhadap Jenis Media Tanam Dan Pupuk Daun. Jurnal Penelitian Pertanian Terapan Vol. 14 (1): 76-82, ISSN 1410-5020

Arif, Irfan. 2015 Rancang Bangun Otomatis Penyiraman Bibit Berbasis Zelio Smart Relay. Tugas Akhir Teknik Elektro Universitas PGRI adi Buana Surabaya.

Djuandi Feri. 2011, Pengenalan Arduino

Gani, Sitti Hardianti, Dahlan dan Anis. 2014, Rancang Bangun sistem Penyiraman Tanaman Secara otomatis Menggunakan soil moisture sonsor Sen00057 Berbasis Mikrokontroller Atmega 328P. Jurnal Fisika Gravitasi Vol.13.Nol 1 ISSN :1412

Hastuti, Vivi. 2013, Pengujian Akurasi Alat Pengukur Suhu dan Kelembaban Menggunakan Sensor SHT1 1 dan Mikrokontroler ATMEGA 8. Jurnal Gema Pendidikan Edisi Juli 2013

Kurniati, Evi, Bambang, dan Tunggal. 2007, Desain Jaringan Irigasi Curah (Sprinkler Irrigation) Pada Tanaman Anggrek. Jurnal Teknologi Pertanian, Vol. 8 No. 1 (April 2007) 35 - 45

Ronaldo Talapessy. 2013, Purwarupa Alat Kontrol Suhu dan Kelembaban Prototype of Temperature and Humidity Control Tools. Prosiding FMIPA Universitas Pattimura 2013 - ISBN: 978-602-97522-0-5

Santo, Bambang Asmoro, Ahmad dan Rita. 2006, Usaha Pembungaan Produk Perawatan Tanaman Anggrek Dendrobium, PS Agronomi, Fakultas Pertanian, Universitas Sebelas Maret, Surakarta

Happy Nugrahaning Widhi dan Heru Winarno. 2017. Sistem Penyiraman Tanaman Anggrek Menggunakan Sensor Kelembaban Dengan Program Borland Delphi 7 Berbasis Modul Arduino. Jurnal Gema TECHNOLOGY Vol. 18 No 1 Tahun2014. 